\title{
Edukasi "Learning By Doing“ Tingkatkan Kesiapan Kader dalam Memberikan Bantuan Hidup Dasar di Puskesmas Pembantu Naimata
}

\author{
Yoani Maria V.B.Aty ${ }^{1(\mathrm{CA})}$ \\ ${ }^{1(\mathrm{CA})}$ Departement of Nursing Poltekkes Kemenkes Kupang; vivi_aty@yahoo.co.id
}

\begin{abstract}
Emergency is a sudden event that occurs anywhere at any time and must be dealt with immediately. More than 30,000 people suffer heart attacks far from health facilities, only 33\% get help from trained lay people. This study is a quantitative research with Quasi experimental design, quasy experiment pre post test design. A total sample of 20 people, the independent variable was Education "Learning By Doing" and the dependent variable was the Readiness Level of Cadres in Naimata Health Center. The results of the study were obtained before the treatment of most respondents were prepared to do basic life assistance, namely 13 people $(65 \%)$ and after treatment 20 respondents $(100 \%)$ were ready to provide Basic Life Assistance. Wilcoxon test results obtained $p$ value of the treatment group 0,000 and $p$ value of the control group 0.012. Mann Whitney U Test obtained p value $=0.617$. Different age and old age level tests for cadres in the control group were obtained $\mathrm{p}<0.005$. So it can be concluded that the factors that influence the readiness of cadres to do Basic Life Assistance are age and length of time to become cadres.
\end{abstract}

Keywords: "Learning by doing" education, cadre, readiness, life basic support.

\begin{abstract}
ABSTRAK
Kegawatdaruratan merupakan kejadian tiba-tiba yang terjadi dimana saja kapan kapan saja dan harus segera ditangani. Lebih dari 30.000 orang menderita serangan jantung jauh dari fasilitas kesehatan, hanya 33\% memperoleh pertolongan dari masyarakat awam terlatih. Studi ini merupakan penelitian kuantitatif dengan desain Quasi experimental, quasy experiment pre post test design. Total sampel 20 orang,Variabel independen adalah Edukasi “ Learning By Doing " dan variabel dependen adalah Tingkat Kesiapan Kader Puskesmas Pembantu Naimata. Hasil penelitian didapatkan sebelum perlakukan sebagian besar responden siap untuk melakukan bantuan hidup dasar yaitu 13 orang ( 65\%) dan sesudah perlakukan 20 responden ( $100 \%$ ) siap untuk memberikan Bantuan Hidup Dasar. Hasil uji Wilcoxon didapatkan p value kelompok perlakuan 0.000 dan p value kelompok kontrol 0.012. Uji Mann Whitney U Test diperoleh nilai $\mathrm{p}=0,617$. Uji beda tingkat usia dan lama menjadi kader pada kelompok control di dapatkan $\mathrm{p}<0.005$. Sehingga dapat disimpulkan bahwa factor yang berpengaruh terhadap kesiapan kader untuk melakukan Bantuan Hidup Dasar adalah usia dan lama menjadi kader.
\end{abstract}

\section{Kata Kunci :Edukasi “Learning By Doing”, Kader, Kesiapan, Bantuan Hidup Dasar}

\section{PENDAHULUAN}

Kegawatdaruratan merupakan kejadian tiba-tiba yang terjadi dimana saja kapan saja dan harus segera ditangani. Kondisi kegawatdaruratan meliputi henti jantung dan napas, kecelakaan dan cedera. Kecelakaan adalah kondisi kesehatan yang amat serius yang terjadi di dunia. Indonesia juga menghadapi berbagai jenis kecelakaan yang mengakibatkan orang menderita sakit dan cedera.

Serangan jantung selalu terjadi di luar rumah sakit. Ada lebih dari 30.000 orang mengalami kondisi serangan jantung di luar rumah sakit dan sekitar $33 \%$ memperoleh penanganan oleh masyarakat awam terlatih. Data World Health Organization (WHO, 2013 : 1), didapatkan bahwa kematian karena kecelakaan lalu lintas diperkirakan terus bertambah yang menyebabkan kematian sekitar 1,9 juta orang per tahun pada tahun 2020. Ini terjadi karena pesatnya pertumbuhan ekonomi, pendapatan yang terus 
meningkat dan kaum urbanisasi yang mengakibatkan permintaan yang besar dalam penggunaan transportasi.

Di Amerika angka kematian rata-rata akibat kecelakaan lalu lintas sebanyak 53,8 per 100.000 penduduk, di Eropa 47,6 per 100.000 penduduk. Pada negara berkembang angka tersebut cenderung lebih tinggi yakni di India 96,7 per 100.000 penduduk dan di negara Asia lainnya 75 per 100.000 penduduk (Utama, dkk. 2008 : 16). Di Indonesia kasus kecelakaan lalu lintas adalah persoalan yang serius. Kecelakaan lalu lintas merupakan pembunuh nomor 3 di Indonesia, karena setiap tahun rata-rata 30.000 orang tidak dapat diselamatkan karena kecelakaan di jalan raya (Russeng, 2008 : 93).

Peristiwa kecelakaan yang membutuhkan pertolongan pertama, yang pertama memberikan bantuan adalah orang yang berada di lokasi kejadian atau anggota keluarga penderita tersebut. Pertolongan dapat diberikan sesuai dengan tingkat kesiapan mulai dari orang yang tidak terlatih sampai mereka yang mungkin sudah terlatih. Bantuan pertama yang diberikan oleh masyarakat untuk korban yang mengalami kecelakaan sering terjadi kesalahan yang fatal bahkan menyebabkan kematian saat memberikan pertolongan. Hal ini terjadi karena kesalahan pertolongan akibat dari masyarakat tidak mengetahui bahwa korban tersebut mengalami multi trauma. Orang yang memberikan pertolongan akan melakukan evakuasi korban kecelakaan dari tempat kejadian ke tempat yang lebih aman tanpa memperhatikan teknik yang tepat sehingga dapat menyebabkan kematian langsung di tempat kejadian.

Masyarakat perlu sigap pada saat menolong korban dengan memberikan bantuan hidup dasar. Tindakan bantuan hidup dasar oleh orang yang berada di sekitar penderita atau korban akan dapat meningkatkan kelangsungan hidup penderita. Gagalnya upaya penyelamatan terhadap korban disebabkan karena tindakan Bantuan Hidup Dasar (BHD) yang tidak sesuai dengan prosedur.

\section{METODE}

Desain atau rancangan penelitian ini adalah Quasy eksperimen dengan jenis penelitian two-group pretest-posttest design. Populasi targetnya adalah kader yang ada di Puskesmas Pembantu Naimata Kota Kupang, yang berjumlah 36 orang. Besarnya sampel yang memenuhi criteria inklusi dalam penelitian ini adalah 20 orang kelompok control dan 20 orang kelompok perlakuan. Teknik sampling yang digunakan dalam penelitian ini adalah Nonprobability sampling yaitu pemilihan sampel dengan total sampling.

\section{HASIL}

1. Karakteristik responden

Tabel 1. Karakteristik Responden Kader Kesehatan Di Puskesmas Pembantu Naimata (n=40)

\begin{tabular}{|c|c|c|c|c|c|}
\hline \multirow{2}{*}{ No } & \multirow{2}{*}{ Karakteristik } & \multicolumn{2}{|c|}{ Kelompok Perlakuan } & \multicolumn{2}{|c|}{ Kelompok Kontrol } \\
\hline & & $\mathrm{F}$ & $\%$ & $f$ & $\%$ \\
\hline \multirow[t]{5}{*}{1.} & Tingkat Pendidikan & & & & \\
\hline & - Tamat SD & 4 & 20 & 2 & 10 \\
\hline & - Tamat SMP & 5 & 25 & 9 & 45 \\
\hline & - Tamat SMA & 9 & 45 & 9 & 45 \\
\hline & - Sarjana & 2 & 10 & 0 & 0 \\
\hline
\end{tabular}


Yoani Maria V.B. Aty, (2020).

\begin{tabular}{|c|c|c|c|c|c|}
\hline \multirow{2}{*}{ No } & \multirow{2}{*}{ Karakteristik } & \multicolumn{2}{|c|}{ Kelompok Perlakuan } & \multicolumn{2}{|c|}{ Kelompok Kontro } \\
\hline & & $\mathrm{F}$ & $\%$ & $f$ & $\%$ \\
\hline \multirow[t]{6}{*}{2.} & Lama menjadi Kader & & & & \\
\hline & - $1-5$ tahun & 11 & 55 & 1 & 5 \\
\hline & - 6-10 tahun & 1 & 5 & 2 & 10 \\
\hline & - $\quad 11-15$ tahun & 6 & 30 & 6 & 30 \\
\hline & - $\quad 16-20$ tahun & 1 & 5 & 7 & 35 \\
\hline & - $21-25$ tahun & 1 & 5 & 4 & 20 \\
\hline
\end{tabular}

Tabel 1 diatas menunjukkan bahwa sebagian besar responden pada kelompok perlakuan dan kontrol berpendidikan terakhir adalah tamat SMA (45\%). Selanjutnya lama menjadi kader pada kelompok perlakuan berkisar 1-5 tahun ( 55\%) dan kelompok perlakuan 16-20 tahun ( 35\%).

2. Kesiapan Kader Tentang Bantuan Hidup Dasar Sebelum Dan Sesudah Dilakukan Learning By Doing

Tabel 2 Kesiapan Kader Tentang Bantuan Hidup Dasar Sebelum Dan Sesudah Dilakukan Learning By Doing Di Puskesmas Pembantu Naimata (n=40)

\begin{tabular}{lcccccccc}
\hline & \multicolumn{3}{c}{ Kelompok Perlakuan } & \multicolumn{3}{c}{ Kelompok Kontrol } \\
\cline { 2 - 8 } \multicolumn{1}{c}{ Kesiapan kader } & \multicolumn{2}{c}{ Pre Test } & \multicolumn{2}{c}{ Post Test } & \multicolumn{2}{c}{ Pre Test } & \multicolumn{2}{c}{ Post Test } \\
\cline { 2 - 9 } & $\mathrm{f}$ & $\%$ & $\mathrm{f}$ & $\%$ & $\mathrm{f}$ & $\%$ & $\mathrm{f}$ & $\%$ \\
\hline \multirow{2}{*}{ Siap } & 13 & 65 & 20 & 100 & 20 & 100 & 20 & 100 \\
Kurang siap & 7 & 35 & 0 & 0 & 0 & 0 & 0 & 0 \\
Tidak siap & 0 & 0 & 0 & 0 & 0 & 0 & 0 & 0 \\
\hline \multicolumn{1}{c}{ Jumlah } & 20 & 100.0 & 20 & 100.0 & 20 & 100.0 & 20 & 100.0 \\
\hline
\end{tabular}

Tabel 2 menunjukkan bahwa pada kelompok perlakuan hasil pre test sebagian besar responden siap untuk melakukan bantuan hidup dasar (65\%) dan hasil post test 100\% responden siap untuk memberikan Bantuan Hidup Dasar. Sedangkan pada kelompok kontrol menunjukkan bahwa sebelum dan sesudah memberikan modul 100\% siap untuk melakukan Bantuan Hidup Dasar.

3. Analisis Kesiapan kader sebelum dan sesudah dilakukan Learning by Doing

Tabel 3 Analisis Kesiapan kader sebelum dan sesudah dilakukan Learning by Doing

\begin{tabular}{lcccc}
\hline \multicolumn{1}{c}{ Kesiapan Kader } & $\mathrm{n}$ & Mean & Z hitung & P.Value \\
\hline \multirow{2}{*}{ Kelompok perlakuan } & 20 & 0.00 & & \\
& & 3.50 & -3.537 & 0.000 \\
Kelompok Kontrol & 20 & 8,15 & -2.527 & 0.012 \\
\hline
\end{tabular}

Tabel 3 dapat dilihat bahwa nilai signifikansi pada kelompok perlakuan adalah 0.000 p<0.05) sehingga dapat dikatakan ada pengaruh edukasi "learning by doing" terhadap tingkat Kesiapan kader Puskesmas Pembantu Naimata dalam bantuan hidup dasar. Pada kelompok kontrol nilai signifikansi pada kelompok perlakuan adalah $0.012(\mathrm{p}<0.05)$. 
Tabel 4 Perbedaan hasil uji Uji Mann-Whitney

\begin{tabular}{lllll}
\hline \multicolumn{1}{c}{ Kesiapan Kader } & N & Mean & Z hitung & P.Value \\
\hline Kelompok perlakuan & 20 & 21.18 & -0.500 & 0.617 \\
Kelompok Kontrol & 20 & 19.82 & & \\
\hline
\end{tabular}

Dari tabel 4 dapat diketahui bahwa $\mathrm{Z}$ hitung $=-0.500$, dengan ini signifikansi yang diperoleh adalah 0.617 , sehingga dapat dinyatakan bahwa tidak ada perbedaan edukasi "learning by doing" terhadap tingkat Kesiapan kader Puskesmas Pembantu Naimata dalam memberikan Bantuan Hidup Dasar.

\section{PEMBAHASAN}

\section{Kesiapan Kader Tentang Bantuan Hidup Dasar Sebelum Dan Sesudah Dilakukan Learning By Doing}

Hasil penelitian menunjukkan bahwa kesiapan kader untuk memberikan Bantuan Hidup Dasar sebelum dilakukan edukasi Learning By Doing sebagian besar adalah siap dan sesudah dilakukan intervensi semua kader siap untuk memberikan bantuan Hidup Dasar. Pada kelompok kontrol semua responden sebelum dan sesudah diberikan modul siap untuk memberikan Bantuan Hidup Dasar.

Kesiapan kader meningkat karena usia para kader 41-50 tahun, sehat mental dan fisik, pendidikan sebagian besar kader adalah tamat SMA. Pada kelompok kontrol para kader sudah menjalan tugasnya sebagian besar 16-20 tahun. Uji beda tingkat pendidikan pada kedua kelompok di dapatkan $p$ value 0,617 dan uji beda tingkat usia diperoleh $p$ value 0,000. Kondisi internal ini sangat mempengaruhi kesiapan seseorang untuk melakukan suatu tindakan. Kesiapan kader meningkat setelah diberikan Edukasi Learning By Doing, karena dalam metode ini para kader dilatih ketrampilan melakukan Bantuan Hidup Dasar.

Hasil tersebut diatas sesuai dengan hasil penelitian Sari, Arief Norma bahwa pengalaman praktek berpengaruh signifikan terhadap kesiapan kerja. Hasil penelitian lainnya yang dilakukan oleh Muktiani, Eka Evi yang mendapatkan hasil adanya pengaruh praktek kerja terhadap kesiapan kerja. Hasil ini juga didukung oleh teori yang dikemukan oleh Slameto bahwa salah satu faktor yang dapat meningkatkan kesiapan adalah ketrampilan. Ketrampilan yang dilatih meliputi identifikasi korban, teknik membantu korban henti napas dan henti jantung, mengeluarkan benda asing dari saluran pernapasan, memberikan kompresi jantung, menghentikan perdarahan dengan cara balut tekan, balut dan bidai, pertolongan pertama pada luka bakar, teknik mengeluarkan benda sing dari telinga, teknik mengangkat korban, membantu menolong korban yang mengalami keracunan. Ketrampilan ini penting diajarkan kepada masyarakat awam baik para kader, polisi, atau masyarakat lainnya. Hal ini sesuai dengan American Hearth Association ( AHA ) tahun 2015 yang menjelaskan bahwa Bantuan Hidup Dasar bisa dilakukan siapapun, tidak harus tenaga kesehatan. Ketrampilan BHD menjadi penting karena diajarkan bagaimana memberikan pertolongan pertama kepada korban-korban yang mengalami kondisi sakit, cedera dan 
kecelakaan yang sering dijumpai dalam kehidupan sehari-hari, sehingga dapat mengurangi komplikasi lanjut yang berefek pada kematian.

Selain itu Kitab Undang-udang Hukum Pidana pasal 531 menegaskan bahwa" barang siapa menyaksikan sendiri ada orang di dalam bahaya maut,lalai memberikan atau mengadakan pertolongan kepadanya sedang pertolongan itu dapat diberikan atau diadakakannya dengan tidak menguatirkan,bahwa ia sendiri atau orang lain akan kena bahaya dihukum kurungan selama-lamanya 3 bulan atau di denda. Pasal ini berlaku bila pelaku pertolongan pertama dapat melakukan tanpa membahayakan dirinya dan orang lain.

Berdasarkan pedoman yang dikeluarkan oleh AHA 2015 dan KUHP pasal 531 tersebut diatas meningkatkan motivasi para kader untuk dapat memberikan Bantuan Hidup Dasar pada berbagai kondisi sesuai dengan ketrampilan yang pernah diperolehnya dalam kegiatan "Edukasi Learning By Doing”.

\section{Analisis Kesiapan kader sebelum dan sesudah dilakukan Learning by Doing}

Hasil penelitian didapatkan bahwa ada pengaruh edukasi " learning by doing " terhadap tingkat kesiapan kader puskesmas pembantu Naimata dalam memberikan Bantuan Hidup Dasar. Hal ini didasarkan pada hasil uji statistik menggunakan analisis statistik parametrik Wilcoxon dengan nilai signifikansi pada kelompok perlakuan adalah 0.000 ( $\mathrm{p}<0.05)$. Hasil uji Mann Whitney U Test menunjukkan $\mathrm{p}>0,05$ berarti tidak ada pengaruh pengaruh edukasi " learning by doing " terhadap tingkat kesiapan kader puskesmas pembantu Naimata dalam Bantuan Hidup Dasar.

Hasil penelitian ini sesuai dengan penelitian yang dilakukan oleh Hernando,et al, tahun 2016 yang menemukan adanya peningkatan kesiapan melakukan CPR setelah dilakukan pelatihan BLS ( Basic Life Support). Metode penelitian ini adalah dengan memberikan ketrampilan dengan cara belajar dengan melakukan Bantuan Hiduo Dasar. Edukasi " learning by doing " merupakan metode pembelajaran yang bersumber dari pengalaman siswa dengan keluarga dan masyarakatnya membuat siswa familiar dengan apa yang dipelajari. Dewey (Arends, 1997) menjelaskan bahwa kelas seharusnya adalah cermin dari masyarakat luas yang berfungsi sebagai laboratorium belajar pada kehidupan nyata. Tanggung jawab utama guru adalah memotivasi peserta didik untuk belajar secara kooperatif dan memikirkan masalah-masalah sosial yang penting setiap hari. Bersamaan dalam aktivitasnya rnemecahkan masalah di kelompoknya, peserta didik belajar prinsip-prinsip demokrasi melalui interaksi dengan peserta didik lain. Teori ini didukung oleh Thelan (dalam Arends, 1997) berpendapat bahwa kelas haruslah merupakan laboratorium atau miniatur demokrasi yang bertujuan mengkaji masalahmasalah sosial dan masalah antar pribadi.

Dalam proses pembelajaran ini juga diperlihatkan dinamika kelompok, sehingga proses pembelajaran semakin tepat sasaran, selain itu setiap anggota kelompo saling bekerjasama untuk bisa melakukan tindaka. Dalam teori pendidikan yang dikemukan oleh Dewey ditekankan pada pembelajaran Kooperatif. Pembelajaran kooperatif sangat baik untuk mempengaruhi hasil belajar akademik, pencapaian tujuan sosial dan afektif peserta didik. Pembelajaran praktek tidak bisa dihindari. Pembelajaran pratek sangat menguntungkan karena secara langsung dapat mengetahui keterampilan atau kompetensi berhasil dikuasai oleh siswa oleh siswa. 
Teori “learning by doing” yang dikemukakan oleh John Dewey, yang diterapkan pada penelitian ini yaitu mengajarkan para kader tentang bantuan hidup dasar dengan metode praktek. Peneliti memberikan kasus tentang kejadian sakit, kecelakaan dan cedera, lalu meminta kepada para kader untuk memberikan pertolongan kepada korban yang mengalami masalah tersebut sesuai dengan pengetahuan yang dimiliki. Kemudian materi pelatihan diberikan tentang Bantuan Hidup Dasar pada Kondisi sakit, Cedera dan Kecelakaan. Dalam proses edukasi para kader dibentuk kelompok, sehingga memudahkan para instruktur untuk mengontrol pelaksanaan kegiatan. Hal ini sesuai dengan teori yang dikemukan oleh Utomo, Dwi Priyo yang menyatakan bahwa fokus pembelajaran kooperatif tidak saja tertumpu pada apa yang dilakukan peserta didik tetapi juga pada apa yang dipikirkan peserta didik selama aktivitas belajar berlangsung.

Model Pembelajaran Learning By Doing lebih baik jika dibandingkan dengan pembelajaran konvensional, yakni pencapaian hasil belajar yang tinggi, lebih kondusif untuk meningkatkan hubungan antar (pertemanan), lebih sehat secara psikologis, meningkatkan kepercayaan diri dan ketrampilan sosial. Para kader yang terlibat dalam edukasi “ Learning By Doing” saling berinteraksi satu sama lain dalam melakukan tindakan Bantuan Hidup Dasar. Semua anggota kelompok mengambil bagian dalam proses ini, sehingga hasil yang didapatkan pengetahuan dan ketrampilan meningkat, bahkan para kader menyatakan siap untuk memberikan Bantuan Hidup Dasar.

Hasil yang baik ini tidak ditunjang dengan hasil uji statistik Mann Withney, dimana peneliti melakukan uji pada kedua kelompok setelah intervensi.Tentu saja hal ini membuktikan bahwa faktor kesiapan bukan hanya ketrampilan yang meningkat, tetapi juga karena banyak faktor antara lain usia, lama menjadi kader, pelatihan yang pernah diikuti. Pada kelompok kontrol sebagian besar sudah menjadi kader lebih dari 5 tahun, usia 41-50 tahun, serta sebagian besar pernah mengikuti pelatihan tentang penangan TB paru di rumah. Uji beda lama menjadi kader pada kelompok perlakuan dan kontrol didapatkan p value 0.000. Hasil ini ditunjang teori Slameto tahun 2015 yang menjelaskan bahwa prinsip dari kesiapan adalah aspek perkembangan berinteraksi, kematangan jasmani dan pengalaman-pengalaman yang pernah dialami.

Disamping itu pada kelompok kontrol masing-masing kader diberikan modul untuk dibaca. Modul menjadi referensi yang penting untuk mengingkatkan pengetahuan para kader. Para kader tidak diajarkan teknik memberikan Bantuan Hidup Dasar. Berdasarkan hal tersebut diatas dapat dijelaskan bahwa seseorang siap untuk memberikan Bantuan Hidup Dasar jika sudah lama menjadi kader, usia yang sudah mapan, keseriusan dalam melakukan praktek, serta niat yang kuat untuk membantu sesama yang mengalami henti napas, jantung, cedera, kecelakaan.

\section{KESIMPULAN}

Sebelum dilakukan edukasi Learning By Doing sebagian besar kader siap untuk memberikan Bantuan Hidup Dasar dan sesudah dilakukan intervensi semua kader siap untuk memberikan bantuan Hidup Dasar. Pada kelompok kontrol semua responden sebelum dan sesudah diberikan modul siap untuk memberikan Bantuan Hidup Dasar. Faktor yang berpengaruh terhadap kesiapan kader untuk melakukan Bantuan Hidup Dasar adalah usia dan lama menjadi kader. Peneliti merekomendasikan penggunaan 
metode edukasi "Learning by Doing" pada institusi pendidikan khususnya bagi mata kuliah praktek. Penelitian selanjutnya agar menambah jumlah sampel, penilaian yang digunakan bukan hanya pengetahuan tetapi juga ketrampilan diobservasi menggunakan instrumen khusus. Penelitian selanjutnya adalah perlu digali analisis faktor yang mempengaruhi kesiapan kader dalam memberikan BHD.

\section{DAFTAR PUSTAKA}

American Heart Association (2015).2015 American Heart AssociationGuidelines Update for Cardiopulmonary Resuscitation and Emergency Cardiovascular Care. Circulation; 132(suppl 2).

American Red Cross (2014). First Aid/CPR/AED Participant Manual. USA: StayWell Health \& Safety Solutions. Diunduh dari http://www.redcross.org/images/MEDIA_CustomProductCatalog/m55540601_FA-CPR-AEDPart-Manual.pdf

Ambarika, R. (2017, Januari). Efektifitas Simulasi Pre hospital Care terhadap Self Efficacy masyarakat awam dalam memberikan pertolongan pertama pada korban kecelakaan. e journal keperawatan, 8.

Balitbang Kemenkes RI.(2013).Riset Kesehatan Dasar (RISKESDAS). Jakarta: Balitbang Kemenkes RI.

Eliastam, Michael. 1998. "Penuntun Kedaruratan Medis", - Ed. 5, Jakarta : EGC

Effendi, Nasrul, 1998. Dasar-Dasar Perawatan Kesehatan Masyarakat.Jakarta: EGC

Hudak, dan Gallo. 2005. Keperawatan Kritis Pendekatan Holistik. Jakarta: EGC

Info Data. 2014 Situasi Kesehatan Jantung. Jakarta: Pusat Data dan Informasi Kementrian Kesehatan RI.

John Dewey.2002.Experience and Education, alih bahasa John de Santo, Pendidikan dan Pengalaman'Yogyakarta:Kepel Press

Muktiani, E. E. (2014). Pengaruh Praktik Kerja Industri dan Prestasi akademik mata diklat produksti akuntasi terhadap kesiapan kerja siswa kelas XI program keahlian akuntasi SMK Nasional Pati. Economic Education Analysis Journal.

Musliha. 2010. Keperawatan Gawat Darurat. Yogyakarta: Nuha Medika

Ngirarung, e. a. (2017, Februari). Pengaruh Simulasi Tindakan Resusitasi Jantung Paru (RJP ) terhadap tingkat motivasi siswa menolong korban henti jantung di SMA Negeri 9 Binsus Manado. $e$ Journal Keperawatan, 5.

Rab, Dabrani. 1998. Agenda Gawat Darurat (Critikal Care).Bandung: PT. Alumni

Santosa, R., \& Hufad, A. (t.thn.). Dampak Pelatihan Program Rescue Terhadap Peningkatan Tanggap Bencana Para Kader Tim Search And Rescue .

Slameto. (2010). Belajar dan faktor-faktor yang mempengaruhinya. Jakarta: Rineka Cipta.

Sutawijaya,R.B.Gawat (2009) Darurat Panduan Kesehatan Wajib Di Rumah Anda. Jakarta : Briliant Offset.

Turambi, D. E., Killing, M., \& Supit, D. (2016). Pengaruh pelatihan Bantuan Hidup Dasar terhadap peningkatan pengetahuan dan ketrampilan siswa kelas XI dan XII SMA NEgeri 2 Langowan. Buletin Sariputra, 6. 